\title{
Integration of natural science and humanities knowledge in the teaching of applied mathematics to students in the conditions of informatization of education
}

\author{
Viktor S. Kornilov \\ Moscow City University \\ 29 Sheremetyevskaya St, Moscow, 127521, Russian Federation
}

\begin{abstract}
Problem and goal. The success of a variety of applied research based on achievements in applied mathematics presupposes the existence of highly qualified professionals with not only fundamental knowledge in applied mathematics, but applied mathematical thinking and the world of information, able to apply environmental technologies in applied research, to formulate and justify inferences about the results of the study. Such specialists in applied mathematics are able to identify and understand the new information obtained as a result of research in terms of its scientific and humanitarian value. That is why much attention is paid to the training of such highly professional specialists in the field of applied mathematics in Russia.

Methodology. In the process of teaching applied mathematics to students of physics and mathematics and natural science areas of higher education, it is advisable to integrate natural science, humanities, and information technology. At the same time, it is necessary to attract specialists in the field of applied mathematics who have experience in using information technologies to solve applied mathematical problems.

Results. The integration of natural science, humanities, and information technologies in the process of teaching applied mathematics allows students to develop a scientific worldview and information culture, to better understand the approaches and methods of applied mathematics as well as the scientific potential of applied mathematics. In addition, this integration allows to identify the fundamental concepts of scientific disciplines, which may not be the basic disciplines for teaching in the field of applied mathematics, but at the same time, play an important role in the methodology of applied mathematics. For example, such disciplines include computer science, philosophy, etc.

Conclusion. Training classes with students in applied mathematics, which integrates natural science, humanities, information technology allows to identify the humanitarian, scientificeducational and scientific-educational potential of teaching applied mathematics to justify the positive contribution of information technology to develop students' ICT competence.
\end{abstract}

Keywords: training in applied mathematics, natural science and humanities, informatization of education, information technology, student

Problem statement. Achievements of applied mathematics are used in many areas of human activity - space exploration, research of the air space, the earth's environment, the bowels of the world ocean; nuclear power, thermonuclear syn- 
thesis, etc.; industrial production, economics, agriculture; biology, medicine, chemistry, physics, computer science, engineering, etc.; sociological and humanitarian research, and other areas of human activity.

A great contribution to the formation and development of applied mathematics was made by the research of A.A. Andronov, S.N. Bernstein, O.M. Belotserkovsky, E.P. Velikhov, V. Velkovich, N.M. Gunter, J.L. Dalembert, N.E. Zhukovsky, M.V. Keldysh, A.N. Kolmogorov, S.P. Korolev, N.E. Kochin, N.N. Krasovsky, A.N. Krylov, M.A. Lavrentiev, A.M. Lyapunov, O.E.H. Love, D.K. Maxwell, G.I. Marchuk, I. Newton, M.V. Ostrogradsky, Yu.N. Pavlovsky, L. Prandtl, S.D. Poisson, A.A. Samarsky, L.I. Sedov, S.L. Sobolev, V.A. Steklov, D.G. Stokes, A.N. Tikhonov, J.B.J. Fourier, S.A. Chaplygin, V.N. Chelomey, E. Schrodinger, L. Euler and other authors.

Modern applied mathematics has been enriched with new features, including the scientific and cognitive potential of mathematical models, humanitarization, distribution of optimality ideas, algorithmization, increasing the role of general mathematical structures, and other features (see, for example, [1-8]).

New methods and directions of applied mathematics are being developed that allow to study objects, processes and phenomena that may be located at large distances from the researcher and are inaccessible for direct study. This can be water space, land space, air space, or outer space. At the same time, new methods of applied mathematics allow to determine not only their location, but also, for example, their shape, structure of inclusions, and cause-and-effect relationships (see, for example, $[5 ; 6 ; 9 ; 10]$ ). It is also obvious that information is a mobile means of studying both analytical and discrete mathematical models and allows to visualize their solutions.

Method of research. Currently, Russian universities provide training for bachelors and undergraduates in such areas as "Applied mathematics and computer science" (01.03.02 - bachelor's level, 01.04.02 - master's level), "Mechanics and mathematical modeling" (01.03.03 - bachelor's level, 01.04.03 - master's level), "Applied mathematics" (01.03.04 - bachelor's level, 01.04.04 - master's level), "Applied mathematics and physics" (03.03.01 - bachelor's level, 03.04.01 - master's level) [11].

The relevant state educational standards specify the characteristics of such areas of training and professional activity, requirements for the results of educational programs, the structure of educational programs, and other requirements.

In modern conditions, the system of higher mathematics education focuses on the training of creative highly qualified specialists who have not only solid and deep scientific knowledge, analytical and informational thinking, but also are able to show interest in modern problems of world science (see, for example, [12-21]).

Integration of natural, humanities, and information technologies in applied mathematics classes helps motivate students to take an interest in learning and acquire deep and solid knowledge of applied mathematics. Students develop the skills to apply effective mathematical methods and approaches to solve sometimes complex mathematical problems. In addition, students gain invaluable experience in conducting humanitarian analysis of mathematical models that can be used to explore a variety of processes. Students develop a scientific outlook, creative abilities, and ac- 
quire deep knowledge not only in the disciplines that are included in the training program in applied mathematics, but also in some disciplines that are not included in the training program. For example, philosophy. The fact that using modern methods of applied mathematics, namely with the theory and practice of inverse and ill-posed problems it is possible to identify the causal relationships of the studied processes. So by studying cause-and-effect relationships and new scientific information, students master important methods of understanding the world around them, such as theory, experiment, and philosophy. Of course, students pay attention to the fact that new scientific information obtained as a result of research of an applied problem is organically intertwined with fundamental philosophical questions of natural science.

Integration of natural, humanitarian knowledge, and information technologies in teaching applied mathematics makes it possible to implement environmental education of students. The fact is that today more than ever, specialists in the field of ecology are required. Therefore, higher education institutions train specialists in such areas of training as "Ecology and natural use", "Geoecology", "Environmental management", etc. In these areas of training, students are introduced to disciplines whose content is developed on the basis of such scientific fields as ecology, geoecology, applied ecology, biosphere, hydrosphere and other scientific fields. Of course, students are also taught to apply modern environmental technologies in their professional activities.

Currently, a great interest in environmental problems is shown by specialists of various professions-ecologists, physicists, biologists, mathematicians and other specialists. Note such authors as N.V. Bolotelov, Yu.I. Brodsky, A.V. Gagarin, M.M. Elanova, A.V. Ivashchenko, I.S. Ilyasova, G.I. Kushnikova, L.V. Mantatova, E.V. Muraveva, Yu.N. Pavlovsky, A.P. Petrov, E.V. Rakhmatullina, S.A. Stepanov, S.M. Fayrushina and other scientists (see, for example, [22]).

For example, it can also be noted that the integration of natural, humanitarian knowledge, and information technologies in the teaching of applied mathematics allows to identify fundamental concepts of computer science, such as information, modeling, formalization, algorithmization, computational experiment, syntax, semantics, computer graphics, information technology, and other basic concepts of computer science.

Results and discussions. The integration of natural science, humanities, and information technologies in lectures, seminars, and laboratory classes dedicated to teaching applied mathematics allows students to master new subject knowledge not only in applied mathematics, but also in computational mathematics, information technology, and other areas of scientific knowledge.

During the seminars, students are taught the skills to study mathematical models, followed by humanitarian analysis, which involves a deep analysis of environmental aspects, such as the environmental state of the air space, the earth's environment or the water environment.

It is obvious that the knowledge and skills gained by students as a result of such training in applied mathematics will help them to be successful and qualified specialists.

Integration of information technologies in the process of teaching applied mathematics is successfully implemented in laboratory classes, where it is possible to use a wide range of information technologies to solve applied mathematical prob- 
lems. Computer algebra systems, or as they are also called - computer mathematical packages, are among such information technologies. Widely known and widely used in teaching are Mathematica, Maple, Matlab, MathCad and other computer mathematical packages (see, for example, [23-25]).

Such computer technologies with a friendly interface have a great potential that allows to effectively and quickly find solutions to many mathematical problems from the fields of applied mathematics.

Among the advantages of such computer technologies is undoubtedly the ability to demonstrate the obtained solutions in analytical, graphical, and numerical form. Of course, these opportunities are attractive when conducting lectures, since it is possible to implement a visual demonstration method of training. Such computer technologies allow students to quickly find analytical or approximate solutions to various mathematical problems by consistently applying commands.

Conclusion. Integration of natural science and humanitarian knowledge, as well as information technologies in the teaching of applied mathematics in the process of teaching students of higher educational institutions allows students to form a system of fundamental knowledge in applied mathematics; to acquire the skills to apply various information technologies to solve applied mathematical problems and conduct their humanitarian analysis; to realize the role of information technologies in mobile research of applied mathematical problems; to develop their mathematical creativity.

\section{References}

[1] Arsenin VYa. Metody matematicheskoj fiziki i special'nye funkcii [Methods of mathematical physics and special functions]. Moscow: Nauka Publ.; 1984.

[2] Blekhman IM, Myshkis AD, Panovko YaG. Prikladnaya matematika: predmet, logika, osobennosti podhodov [Applied mathematics: subject, logic, features of approaches]. Moscow: KomKniga Publ.; 2005.

[3] Kornilov VS. Gumanitarnye aspekty vuzovskoj sistemy prikladnoj matematicheskoj podgotovki [Humanitarian aspects of the university system of applied mathematical training]. Nauka i shkola [Science and school]. 2007;(5):23-28.

[4] Malineckij GG. Risk, prognoz, haos i prikladnaya matematika [Risk, forecast, chaos and applied mathematics]. Sovremennye problemy prikladnoj matematiki [Modern problems of applied mathematics]: collection of popular science articles (issue 1, pp. 141-196). Moscow: MZ Press; 2005.

[5] Petrov YuP, Sizikov VS. Korrektnye, nekorrektnye i promezhutochnye zadachi s prilozheniyami [Correct, incorrect and intermediate tasks with applications]: textbook. Saint Petersburg: Politekhnika Publ.; 2003.

[6] Romanov VG. Ustojchivost' v obratnyh zadachah [Stability in inverse problems]. Moscow: Nauchnyj mir Publ; 2005.

[7] Sovremennye problemy prikladnoj matematiki [Modern problems of applied mathematics]: collection of popular science articles (issue 1). Moscow: MZ Press; 2005.

[8] Bidaibekov EY, Kornilov VS, Saparbekova GA. Implementation of Humanitarian Components of Applied Mathematics Teaching for University Students with a Specialization in Science. Indian Journal of Science and Technology. 2016;9(29). DOI: 10.17485/ijst/2016/v9i29/88842.

[9] Vabishevich PN. Vychislitel'nye metody matematicheskoj fiziki. Obratnye zadachi $i$ zadachi upravleniya [Computational methods of mathematical physics. Inverse problems and management problems]. Moscow: Vuzovskaya kniga Publ.; 2019. 
[10] Kornilov VS. Teoriya i metodika obucheniya obratnym zadacham dlya differencial'nyh uravnenij [Theory and method of teaching inverse problems for differential equations]: monograph. Moscow: OntoPrint Publ.; 2017.

[11] Federal'nye gosudarstvennye obrazovatel'nye standarty vysshego obrazovaniya Rossijskoj Federacii [Federal state educational standards of higher education of the Russian Federation]. Available from: https://fgos.ru/ (accessed: 26.05.2020).

[12] Boronenko TA, Fedotova VS. Formirovanie IKT-kompetentnosti nauchno-pedagogicheskih kadrov $\mathrm{v}$ trekhurovnevoj sisteme vysshego obrazovaniya [Formation of ICT competence of scientific and pedagogical personnel in the three-level system of higher education]. Obrazovanie i nauka [Education and science]. 2016;(1):95-106.

[13] Buzhinskaya NV. Metodika ocenki urovnya IKT-kompetentnosti studentov pedagogicheskih vuzov [Methodology for assessing the level of ICT competence of students of pedagogical universities]. Vestnik Bryanskogo gosudarstvennogo universiteta [Bulletin of the Bryansk state University]. 2016;1(27):319-324.

[14] Veselova EA. Formirovanie nauchnogo mirovozzreniya studentov v obrazovatel'novospitatel'nom processe vysshej shkoly [Formation of scientific worldview of students in the educational process of higher school]. Dissertation of the Candidate of Pedagogical Sciences. Nizhnij Novgorod; 2008.

[15] Efremenkova OV. Gumanitarno-orientirovannye matematicheskie zadachi v processe razvitiya tvorcheskoj aktivnosti studentov $v$ tekhnicheskom vuze [Humanities-oriented mathematical problems in the development of creative activity of students in a technical university]. Dissertation of the Candidate of Pedagogical Sciences. Barnaul; 2003.

[16] Komissarova SA. Zadachnaya tekhnologiya kak sredstvo gumanitarizacii estestvennonauchnogo obrazovaniya [Task technology as a means of humanitarization of natural science education]. Dissertation of the Candidate of Pedagogical Sciences. Volgograd; 2002.

[17] Kornilov VS. Psihologicheskie aspekty obucheniya studentov vuzov fraktal'nym mnozhestvam [Psychological aspects of teaching university students fractal sets]. Bulletin of People's Friendship University of Russia. Series: Informatization of Education]. 2011;(4):79-82.

[18] Kornilov VS. Obuchenie studentov obratnym zadacham dlya differencial'nyh uravnenij kak faktor formirovaniya kompetentnosti $\mathrm{v}$ oblasti prikladnoj matematiki [Teaching students inverse problems for differential equations as a factor of competence formation in the field of applied mathematics]. Bulletin of Peoples' Friendship University of Russia. Series: Informatization of Education. 2015;(1):63-72.

[19] Kornilov VS. Realizaciya nauchno-obrazovatel'nogo potenciala obucheniya studentov vuzov obratnym zadacham dlya differencial'nyh uravnenij [Realization of scientific and educational potential of teaching university students inverse problems for differential equations]. Kazanskij pedagogicheskij zhurnal [Kazan pedagogical journal]. 2016;(6):55-59.

[20] Levchenko IV, Kornilov VS, Belikov VV. Rol' informatiki v podgotovke specialistov po prikladnoj matematike [Role of computer science in the training of specialists in applied mathematics]. Vestnik Moskovskogo gorodskogo pedagogicheskogo universiteta. Seriya: Informatika i informatizacija obrazovanija [Bulletin of the Moscow City Pedagogical University. Series: Informatics and Informatization of Education]. 2009;2(18): 108-112.

[21] Malygina OA. Obuchenie vysshej matematike na osnove sistemno-deyatel'nostnogo podhoda [Teaching higher mathematics on the basis of a system-activity approach]: textbook. Moscow: LKI Publ.; 2008.

[22] Ivashchenko AV, Gagarin AV, Stepanov SA. Cennostnyj podhod k formirovaniyu professional'no-ekologicheskoj kul'tury budushchego specialista [Value approach to the formation of professional and environmental culture of the future specialist]. Vestnik Moskovskogo gosudarstvennogo gumanitarnogo universiteta imeni M.A. Sholohova [Bulle- 
tin of the Moscow State University for the Humanities named after M.A. Sholokhov]. 2012;1(1):58-67.

[23] Goloskokov DP. Uravneniya matematicheskoj fiziki. Reshenie zadach v sisteme Maple [Equations of mathematical physics. Solving problems in the Maple system]: textbook for universities. Saint Petersburg: Piter Publ.; 2004.

[24] Kornilov VS. Teoreticheskie osnovy informatizacii prikladnogo matematicheskogo obrazovaniya [Theoretical bases of informatization of applied mathematical education]: monograph. Voronezh: Nauchnaya kniga Publ.; 2011.

[25] Edvards ChG, Penni DE. Differencial'nye uravneniya i kraevye zadachi: modelirovanie $i$ vychislenie s pomoshch'yu Mathematica, Maple i Matlab [Differential equations and boundary value problems: modeling and computation using Mathematica, Maple and Matlab]: textook. Moscow: Vilyams Publ.; 2008.

\title{
Article history:
}

Received: 10 March 2020

Accepted: 13 April 2020

\section{For citation:}

Kornilov VS. Integration of natural science and humanities knowledge in the teaching of applied mathematics to students in the conditions of informatization of education. RUDN Journal of Informatization in Education. 2020;17(3):229-236. http://dx.doi.org/10.22363/ 2312-8631-2020-17-3-229-236

\section{Bio note:}

Viktor S. Kornilov, candidate of physical and mathematical sciences, doctor of pedagogical sciences, full professor, professor of the department of informatization of education of the Moscow City University. E-mail: vs_kornilov@mail.ru

\section{Интеграция естественно-научных и гуманитарных знаний в преподавании прикладной математики студентам в условиях информатизации образования}

\author{
В.С. Корнилов \\ Московский городской педагогический университет \\ Российская Федерация, 127521, Москва, ул. Шереметьевская, 29
}

\begin{abstract}
Аннотация. Проблема и цель. Успешность проведения разнообразных прикладных исследований на основе достижений прикладной математики предполагает наличие высокопрофессиональных специалистов, обладающих не только системой фундаментальных знаний в этой области, но и прикладным математическим мышлением и информационной культурой, умеющих применять природоохранные технологии в прикладных исследованиях, способных самостоятельно формулировать и обосновывать логические выводы о полученных результатах проведенного исследования. Такие специалисты по прикладной математике могут выявить и осмыслить полученную в результате исследования новую информацию с точки зрения ее научности и гуманитарной ценно-
\end{abstract}


сти, поэтому подготовке именно таких высокопрофессиональных кадров в области прикладной математики в России уделяется большое внимание.

Методология. В процессе обучения прикладной математике студентов физикоматематических и естественно-научных направлений подготовки высших учебных заведений целесообразно интегрировать естественно-научные и гуманитарные знания и информационные технологии. При этом необходимо привлекать для обучения прикладной математике специалистов в данной области, которые имеют опыт применения информационных технологий для решения прикладных математических задач.

Результаты. Интеграция естественно-научных и гуманитарных знаний и информационных технологий в процессе обучения прикладной математике дает возможность студентам развить научное мировоззрение и информационную культуру, глубже осмыслить подходы и методы прикладной математики и понять ее научный потенциал. Кроме того, отмеченная интеграция способствует выявлению фундаментальных понятий научных дисциплин, которые могут и не являться базовыми при обучении по направлению прикладной математики, но при этом играют важную роль в ее методологии. Среди таких дисциплин, например, информатика, философия и др.

Заключение. Проведение учебных занятий со студентами по прикладной математике, в которых реализована интеграция естественно-научных и гуманитарных знаний и информационных технологий, позволяет выявить гуманитарный, научно-образовательный и научно-познавательный потенциал обучения прикладной математике, обосновать позитивный вклад информационных технологий в развитие у студентов ИКТ-компетентности.

Ключевые слова: обучение прикладной математике, естественно-научные и гуманитарные знания, информатизация образования, информационные технологии, студент

\section{Список литературы}

[1] Арсенин В.Я. Методы математической физики и специальные функции. М.: Наука, 1984. $383 \mathrm{c}$.

[2] Блехман И.М., Мышкис А.Д., Пановко Я.Г. Прикладная математика: предмет, логика, особенности подходов. М.: КомКнига, 2005. 376 с.

[3] Корнилов B.C. Гуманитарные аспекты вузовской системы прикладной математической подготовки // Наука и школа. 2007. № 5. С. 23-28.

[4] Малинецкий Г.Г. Риск, прогноз, хаос и прикладная математика // Современные проблемы прикладной математики: сборник научно-популярных статей / под ред. А.А. Петрова. М.: МЗ Пресс, 2005. Вып. 1. С. 141-196.

[5] Петров Ю.П., Сизиков В.С. Корректные, некорректные и промежуточные задачи с приложениями: учебное пособие. СПб.: Политехника, 2003. 261 с.

[6] Романов В.Г. Устойчивость в обратных задачах. М.: Научный мир, 2005. 296 с.

[7] Современные проблемы прикладной математики: сборник научно-популярных статей / под ред. А.А. Петрова. М.: МЗ Пресс, 2005. Вып. 1. 231 с.

[8] Bidaibekov E.Y., Kornilov V.S., Saparbekova G.A. Implementation of Humanitarian Components of Applied Mathematics Teaching for University Students with a Specialization in Science // Indian Journal of Science and Technology. August 2016. Vol. 9. No. 29. DOI: $10.17485 / \mathrm{ijst} / 2016 / \mathrm{v} 9 \mathrm{i} 29 / 88842$.

[9] Вабишевич П.Н. Вычислительные методы математической физики. Обратные задачи и задачи управления. М.: Вузовская книга, 2019. 478 с.

[10] Корнилов В.С. Теория и методика обучения обратным задачам для дифференциальных уравнений: монография. М.: ОнтоПринт, 2017. 500 с.

[11] Федеральные государственные образовательные стандарты высшего образования Российской Федерации. URL: https://fgos.ru/ (дата обращения: 26.05.2020).

[12] Бороненко Т.А., Федотова В.С. Формирование ИКТ-компетентности научнопедагогических кадров в трехуровневой системе высшего образования // Образование и наука, 2016. № 1. С. 95-106. 
[13] Бужинская Н.В. Методика оценки уровня ИКТ-компетентности студентов педагогических вузов // Вестник Брянского государственного университета. 2016. № 1 (27). C. 319-324.

[14] Веселова Е.А. Формирование научного мировоззрения студентов в образовательновоспитательном процессе высшей школы: дис. ... канд. пед. наук. Нижний Новгород, 2008. $255 \mathrm{c}$.

[15] Ефременкова О.В. Гуманитарно-ориентированные математические задачи в процессе развития творческой активности студентов в техническом вузе: дис... канд. пед. наук. Барнаул, 2003. 203 с.

[16] Комиссарова С.А. Задачная технология как средство гуманитаризации естественнонаучного образования: дис. ... канд. пед. наук. Волгоград, 2002. 215 с.

[17] Корнилов B.C. Психологические аспекты обучения студентов вузов фрактальным множествам // Вестник Российского университета дружбы народов. Серия: Информатизация образования. 2011. № 4. С. 79-82.

[18] Корнилов В.С. Обучение студентов обратным задачам для дифференциальных уравнений как фактор формирования компетентности в области прикладной математики // Вестник Российского университета дружбы народов. Серия: Информатизация образования. 2015. № 1. С. 63-72.

[19] Корнилов В.С. Реализация научно-образовательного потенциала обучения студентов вузов обратным задачам для дифференциальных уравнений // Казанский педагогический журнал. 2016. № 6. С. 55-59.

[20] Левченко И.В., Корнилов В.С., Беликов В.В. Роль информатики в подготовке специалистов по прикладной математике // Вестник Московского городского педагогического университета. Серия: Информатика и информатизация образования. 2009. № 2 (18). С. 108-112.

[21] Мальгина O.A. Обучение высшей математике на основе системно-деятельностного подхода: учебное пособие. М.: Изд-во ЛКИ, 2008. 256 с.

[22] Ивашенко А.В., Гагарин А.В., Степанов С.A. Ценностный подход к формированию профессионально-экологической культуры будущего специалиста // Вестник Московского государственного гуманитарного университета имени М.А. Шолохова. 2012. Т. 1. № 1. С. 58-67.

[23] Голоскоков Д.П. Уравнения математической физики. Решение задач в системе Maple: учебник для вузов. СПб.: Питер, 2004. 539 с.

[24] Корнилов В.С. Теоретические основы информатизации прикладного математического образования: монография. Воронеж: Научная книга, 2011. 140 с.

[25] Эдвардс Ч.Г., Пенни Д.Э. Дифференциальные уравнения и краевые задачи: моделирование и вычисление с помощью Mathematica, Maple и Matlab: учебник. М.: Вильямс, 2008. 1097 с.

\section{История статьи:}

Дата поступления в редакцию: 10 марта 2020 г.

Дата принятия к печати: 13 апреля 2020 г.

\section{Для цитирования:}

Kornilov V.S. Integration of natural science and humanities knowledge in the teaching of applied mathematics to students in the conditions of informatization of education // Вестник Российского университета дружбы народов. Серия: Информатизация образования. 2020. T. 17. № 3. C. 229-236. http://dx.doi.org/10.22363/2312-8631-2020-17-3-229-236

\section{Сведения об авторе:}

Корнилов Виктор Семенович, кандидат физико-математических наук, доктор педагогических наук, профессор, профессор кафедры информатизации образования Московского городского педагогического университета. E-mail: vs_kornilov@mail.ru 